\title{
PERAN PENDAMPING SERTA DAMPAK ANGGARAN DI BIDANG KELAUTAN DAN PERIKANAN TERHADAP KONDISI KESEJAHTERAAN MASYARAKAT NELAYAN DI KABUPATEN ENDE
}

\section{THE ROLE OF ASSISTANCE AND BUDGET IMPACTS IN THE FIELD OF MARINE AND FISHERIES ON WELFARE CONDITIONS OF FISHERMEN COMMUNITY IN ENDE DISTRICT}

\author{
Baltasar Taruma Djata \\ Dosen Fakultas Ekonomi Universitas Flores Ende, Nusa Tenggara Timur \\ Email: elang ek@yahoo.com
}

\begin{abstract}
ABSTRAK
Penelitian ini bertujuan: 1). Mengetahui peran pendamping dalam memberdayakan kelompok nelayan perikanan tangkap, yang merupakan kelompok sasaran bantuan anggaran pendampingan; 2). Mengetahui pendekatan serta strategi pendampingan terhadap kelompok nelayan perikanan tangkap, sebagai sasaran bantuan anggaran pendampingan; 3). Mengetahui pengaruh anggaran di bidang kelautan dan perikanan terhadap kondisi kesejahteraan Masyarakat Nelayan di Kabupaten Ende; 4). Mengetahui efektifitas anggaran di bidang kelautan dan perikanan terhadap kondisi kesejahteraan masyarakat nelayan di Kabupaten Ende.

Adapun hasil analisisnya adalah Kelompok nelayan menunjukkan respon baik kalau aktivitasnya sebagai nelayan selalu dalam pendampingan, pembinaan, penyuluhan dan pengawasan oleh pemerintah atau juga tenaga pendamping khusus. Hal ini karena pendamping memiliki peran yang strategis dalam proses pemberdayaan, termasuk di dalamnya adalah pemberdayaan terhadap kelompok nelayan. Dalam kegiatan pendampingan menggunakan pendekatan Sosio Ekonomis, yakni pendekatan yang melihat masyarakat yang lemah dan miskin tersebut akan mampu mengatasi persoalan mereka bila kemampuan ekonomisnya ditingkatkan.

Strategi pendampingan dilakukan melalui tahapan pendampingan mulai dari tahap pertemuan awal, kunjungan dan observasi lapangan, pembahasan hasil observasi, perbaikan berdasarkan hasil observasi, penyusunan laporan, dan tahap distribusi laporan kegiatan pendampingan kepada instansi terkait.

Anggaran pendampingan berpengaruh signifikan terhadap kondisi kesejahteraan masyarakat nelayan dan mempunyai kontribusi terhadap kondisi kesejahteraan masyarakat nelayan.

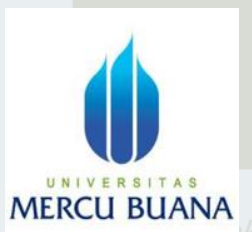

Jurnal Perilaku Dan Strategi bisnis

Vol.6 No.1, 2018

Hal. $78-102$
\end{abstract}

Kata kunci: Pendamping, Anggaran, Perikanan, Kelautan, Semi log, Kesejahteraan, Nelayan 


\begin{abstract}
This study aims: 1). to know the role of assistant in empowering fishery catching fishermen group, which is target group of assistance budget assistance; 2). to know approach and strategy of facilitation to fishery fishermen group, as target of budget assistance; 3). to find out the influence of budget in marine and fisheries to the welfare condition of Fishermen Society in Ende Regency; 4). to find out the effectiveness of the budget in the field of marine and fisheries to the welfare conditions of fishing communities in Ende District. The analysis results are Fishermen group shows good response if their activity as fisherman always in assistance, coaching, counseling and supervision by government or also special escort. This is because the companion has a strategic role in the empowerment process, including the empowerment of the fishermen group. In advisory activities using the Socioeconomic approach, an approach that sees weak and poor communities will be able to overcome their problems if their economic capacity is improved. Mentoring strategy is done through the stages of facilitation starting from the initial meeting stage, visits and field observations, discussion of observation results, improvements based on observation, compilation of reports, and stage of distribution of reports of mentoring activities to relevant agencies. The budget of assistance has a significant effect on the welfare condition of the fishermen community and has contributed to the welfare condition of the fishermen community.
\end{abstract}

Keywords: Companion, Budget, Fishery, Marine, Semi log, Welfare, Fisherman.

\title{
PENDAHULUAN
}

Indonesia adalah negara kepulauan dimana sekitar 75 persen wilayahnya berupa laut dengan lebih dari 17.000 pulau, serta panjang garis pantai nomor 4 di dunia yaitu $95.181 \mathrm{~km}$ (World Resources Institute tahun 2001, dalam Ramadona, 2011). Kondisi ini juga didukung dengan jumlah nelayan (laut dan perairan umum) di Indonesia mencapai lebih dari 2.755.794 orang. (Keputusan Menteri Kelautan dan Perikanan RI, Nomor 18 tahun 2011).

Gambaran kondisi di Propinsi Nusa Tenggara Timur (NTT) umumnya dan Kabupaten Ende khususnya dapat dilihat melalui jumlah rumah tangga pengusaha perikanan laut maupun produksi perikanan laut selama tahun 2011-2015.

Berikut ini jumlah rumah tangga perikanan laut di Propinsi NTT dan Kabupaten Ende selama tahun 2011-2015.

\section{Tabel 1 \\ Jumlah Rumah Tangga Pengusaha Perikanan Laut di Kabupaten Ende dan Propinsi NTT Tahun 2011-2015}

\begin{tabular}{lcc}
\hline Tahun & Ende & NTT \\
\hline 2011 & 475 & 14.982 \\
2012 & 1.659 & 24.464 \\
2013 & 1.659 & 24.464 \\
2014 & 4.996 & 36.850 \\
2015 & 3.165 & 30.761 \\
\hline
\end{tabular}

Sumber : www.bps.go.id dan berbagai sumber

Sementara kalau dilihat hasil produksi perikanan laut Propinsi Nusa Tenggara Timur (NTT) selama tahun 2011-2015 didominasi tren yang terus meningkat dari tahun ke tahun. Berikut ini adalah produksi perikanan laut di Propinsi NTT selama tahun 2011-2015: 
Tabel 2

\begin{tabular}{cc}
$\begin{array}{c}\text { Produksi Ikan Laut (ton) di Propinsi } \\
\text { Selama Tahun 2011- 2015 }\end{array}$ \\
\hline Tahun & Produksi (Ton) \\
\hline 2011 & $267,631.05$ \\
2012 & $54,223.50$ \\
2013 & $74,020.90$ \\
2014 & $93,818.30$ \\
2015 & $2,762.30$ \\
\hline
\end{tabular}

Sumber: www.bps.go.id dan berbagai sumber

Dilihat dari tabel 2 di atas, dapat dijelaskan bahwa produksi perikanan laut di Propinsi NTT pada tahun 2011 adalah 267,631.05 ton. Terjadi penurunan produksi pada tahun 2012, yakni hanya mampu memproduksi sebesar 54,223.50, tahun 2013 memproduksi sebesar 74,020.90 ton serta tahun 2014 dan 2015 memproduksi sebesar 93,818.30 ton dan 2.762,30 ton. Produksi perikanan Kabupaten Ende selama tahun 2011-2015 dapat disajikan dalam tabel 3 berikut ini:

Tabel 3

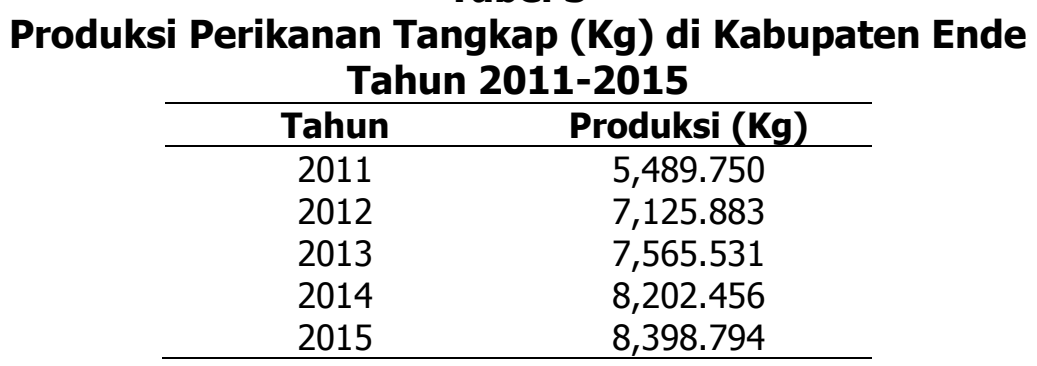

Sumber: DKP Ende.

Dari tabel 3 tersebut di atas dapat dijelaskan bahwa produksi perikanan tangkap di Kabupaten Ende selama tahun 2011-2015 trennya meningkat terus. Pada tahun 2011 memproduksi sejumlah $5.489,750 \mathrm{~kg}$, tahun 2012 produksi mengalami peningkatan sejumlah $1.636,133 \mathrm{~kg}$ atau mampu memproduksi sejumlah 7.125,883 kg, tahun 2013 meningkat lagi sejumlah 439,648 kg atau mampu memproduksi sebanyak $7.565,531 \mathrm{~kg}$, tahun 2014 memproduksi sebanyak $8.202,456 \mathrm{~kg}$ atau mengalami peningkatan sebesar 636,925 kg sedangkan pada tahun 2015 memproduksi sebanyak 8.398,794 atau kegiatan produksi meningkat sejumlah $196,338 \mathrm{~kg}$.

Dilihat dari hasil produksi perikanan tersebut di atas maka dapat disimpulkan bahwa kontribusi produksi perikanan tangkap mempunyai kecenderungan yang meningkat terus selama tahun 2011-2015. Kalau Ramadona (2011) mengatakannya bahwa sektor perikanan dengan segenap potensi yang besar memiliki peluang menjadi tulang punggung pembangunan bangsa ini.

Pembangunan sektor kelautan dan perikanan selama ini selalu menjadi sektor pinggiran dalam pembangunan ekonomi nasional (Ramadona, 2011). Implikasi dari tidak adanya prioritas kebijakan pembangunan perikanan tersebut, mengakibatkan sangat minimnya perikanan di wilayah pesisir, terjadinya abrasi wilayah pesisir dan pantai, pengrusakan ekositem laut dan terumbu karang, serta belum optimalnya pemanfaatan sumberdaya perikanan dan kelautan. Harus diakui bahwa pemerintahan orde baru lebih memfokuskan perhatian pembangunan di darat dan mengesampingkan pembangunan di sektor perikanan dan kelautan sehingga akibat yang terjadi adalah nelayan tetap dengan ketertinggalannya dan tetap miskin, sementara sektor perikanan dan kelautan di propinsi Nusa Tenggara Timur sangat kaya akan potensi laut dengan keanekaragaman hayatinya sehingga apabila 
dikelola dengan baik dan bertanggung jawab maka akan menjadi aset yang dapat mendukung pertumbuhan ekonomi pemerintah di Era otonomi daerah dan mendukung eksport untuk peningkatan devisa negara.

Bersamaan dengan arus reformasi yang sedang berjalan, pemikiran ke arah ekonomi daerah menjadi perhatian baru dalam pengelolaan sumberdaya masyarakat pesisir dan kelautan di Indonesia. Hadirnya otonomi daerah diharapkan untuk dapat memberi kesempatan pemerataan hasil-hasil pembangunan termasuk di dalamnya adalah pengelolaan sumberdaya masyarakat pesisir dan kelautan. Selanjutnya menurut Rudiyanto dalam atikel yang bejudul: Kerangka kerjasama dalam pengelolaan sumberdaya pesisir dan laut (http.www.bappenas.go.id) mengatakan bahwa peran pemerintah daerah di era otonomi diharapkan dapat mengelola sumberdaya pesisir dan laut, secara lebih rasional mengingat ketersediaan sumberdaya serta terdegradasinya sumberdaya akan menentukan tingkat kemakmuran masyarakat didaerah yang bersangkutan. Namun diharapkan kebijakan pembangunan perikanan yang dijalankan semestinya tidak hanya mengejar kepentingan ekonomi (Khususnya hanya meningkatkan penerimaan devisa negara, daerah dan export hasil laut), tetapi juga diimbangi secara operasional dengan komitmen menjaga kelestarian sumberdaya perikanan yang ada serta mendukung usaha nelayan dengan sarana produksi dan modal usaha terhadap nelayan untuk mengembangkan usaha.

Sekarang ini pembangunan daerah pesisir mulai menjadi fokus utama akibat ketertinggalan pada masyarakat pesisir, karena terbatasnya dalam mengakses sumber permodalan dan lemahnya infrastruktur kelembagaan sosial ekonomi masyarakat yang ada di desa. Kondisi seperti ini membuat masyarakat pesisir semakin tertinggal dan bahkan Produk Domestik Bruto (PDB) Perikanan baru memberikan kontribusinya sebesar 3,2\%, produksi perikanan tangkap di lautnya 4,7 ton pertahun, dan nelayan masih miskin. (Keputusan Menteri Kelautan dan Perikanan RI, Nomor 18 tahun 2011).

Kabupaten Ende sebagai bagian integral dari Negara Kesatuan Republik Indonesia (NKRI) juga menghadapi kondisi riil sebagaimana diuraikan terdahulu, yang mana dengan kondisi riil yang memprihatinkan itu membutuhkan perhatian bersama, terutama konsentrasi anggaran yang berpihak pada pengelolaan sumber daya perikanan dan kelautan.

Berikut ini dapat disajikan besarnya anggaran pendampingan terhadap kelompok nelayan yang ditujukan untuk perikanan dan kelautan di Kabupaten Ende yang memiliki panjang Pantai di Wilayah Utara sepanjang 60 mil atau $111.120 \mathrm{Km}$ dan Pantai Selatan sepanjang 51 mil atau $94.452 \mathrm{Km}$. (www.endekab.go.id). Adapun anggaran pendampingan terhadap kelompok nelayan yang diterima DKP Kabupaten Ende rinciannya di tabel 4.

\section{Tabel 4}

$\begin{array}{cc}\text { Jumlah Anggaran Pendampingan Terhadap Kelompok Nelayan } \\ \text { di Kabupaten Ende, Tahun 2011-2015 } \\ \text { Tahun } & \begin{array}{c}\text { Pendampingan Pada } \\ \text { Kelompok Nelayan Perikanan } \\ \text { Tangkap }\end{array} \\ & 1,915,082,749 \\ 2011 & 2,224,222,000 \\ 2012 & 2,742,893,600 \\ 2013 & 3,758,251,000 \\ 2014 & 3,165,932,600 \\ 2015 & \end{array}$

Sumber: BAPPEDA dan DKP Kabupaten Ende

Anggaran pendampingan terhadap kelompok nelayan selama tahun 2011-2015 trennya meningkat dari tehun ke tahun. Pada tahun 2011 anggaran sejumlah Rp 1.915.082.749, tahun 2012 meningkat menjadi Rp 2.224.222.000, tahun 2013 adalah sejumlah Rp 2.742.893.600, pada tahun 2014 meningkat dengan jumlah Rp 3.758.251.000 sedangkan 
pada tahun 2015 menurun menjadi 3.165 .932 .600 atau berkurang sejumlah $\mathrm{Rp}$ 592.318.400.

Jumlah anggaran yang diberikan tersebut di atas dipergunakan untuk kegiatan pendampingan terhadap kelompok nelayan, dengan keadaan anggota kelompok seperti terlihat dalam tabel 5 berikut ini:

Tabel 5

Jumlah Anggota Kelompok Nelayan di Kabupaten Ende Tahun 2011-2015

\begin{tabular}{cc}
\hline Tahun & Jumlah (org) \\
\hline 2011 & 2,447 \\
2012 & 2,453 \\
2013 & 2,619 \\
2014 & 2,719 \\
2015 & 2,745 \\
\hline
\end{tabular}

Sumber: www.bps.go.id dan Ende

Dalam rangka menciptakan efektifitas dan efisiensi pemanfaatan anggaran di bidang kelautan dan perikanan maka memerlukan pendampingan. Pendampingan akan berarti jika pendamping mampu mendampingi kelompok dampingannya melalui kerangka kerja dengan metode dan strategi yang terarah sehingga mampu menjangkau kemampuan kelompok nelayan dampingan yang memiliki ciri, karakteristik dan pola pikir yang berbeda. Pendekatan dan strategi yang dimiliki pendamping merupakan bagian dari kompetensi yang dimiliki oleh pendamping.

\section{Tujuan Penelitian}

Adapun tujuan dari penelitian ini adalah:

1. Mengetahui peran pendamping dalam memberdayakan kelompok nelayan perikanan tangkap, yang merupakan kelompok sasaran bantuan anggaran pendampingan.

2. Mengetahui pendekatan serta strategi pendampingan terhadap kelompok nelayan perikanan tangkap, sebagai sasaran bantuan anggaran pendampingan.

3. Mengetahui pengaruh anggaran di bidang kelautan dan perikanan terhadap kondisi kesejahteraan Masyarakat Nelayan di Kabupaten Ende.

4. Mengetahui efektifitas anggaran di bidang kelautan dan perikanan terhadap kondisi kesejahteraan masyarakat nelayan di Kabupaten Ende.

\section{Kegunaan Penelitian}

Diharapkan agar penelitian ini dapat berguna bagi:

1. Masyarakat nelayan mengetahui pendekatan serta strategi pendampingan maupun kontribusi anggaran sektor perikanan dan kelautan yang turut mempengaruhi kondisi kesejahteraan masyarakat nelayan.

2. Pemerintah Daerah, sebagai bahan rekomendasi dalam penetapan kebijakan anggaran bagi sektor perikanan dan kelautan dalam rangka meningkatkan struktur kesejahteraan masyarakat nelayan yang diindikasikan lewat pendapatan perkapitanya.

\section{TINJAUAN PUSTAKA}

\section{Sumberdaya Pesisir dan Laut}

Wilayah pesisir yang merupakan sumberdaya potensial di Indonesia, yang merupakan suatu wilayah peralihan antara daratan dan lautan (Yuniarti, 2007). Sumberdaya ini sangat besar yang didukung oleh adanya garis pantai sepanjang sekitar $81.000 \mathrm{~km}$ (Dahuri et al. 2001, dalam Yuniarti, 2007). Garis pantai yang panjang ini menyimpan potensi kekayaan sumber alam yang besar. Potensi itu diantaranya potensi hayati dan non hayati. Potensi hayati misalnya: perikanan, hutan mangrove, dan terumbu karang, sedangkan potensi nonhayati 
misalnya: mineral dan bahan tambang serta pariwisata. Uraian selanjutnya dalam penelitian ini adalah yang terkait dengan potensi hayati saja. Potensi hayati tersebut yakni perikanan, hutan mangrove, dan terumbu karang.

\section{Perikanan}

Lautan Indonesia merupakan wilayah Marine Mega-Biodiversity terbesar di dunia, memiliki 8.500 species ikan. (Siregar. 2015) Sedangkan estimasi potensi sumberdaya ikan pada masing-masing wilayah pengelolaan perikanan Republik Indonesia seperti terlihat dalam tabel 6 berikut:

Tabel 6

Estimasi Potensi Sumberdaya Ikan Pada Masing-Masing Wilayah Pengelolaan Perikanan Republik Indonesia (dalam ribu ton/tahun

\begin{tabular}{|c|c|c|c|c|c|c|c|c|c|c|c|c|}
\hline \multirow{2}{*}{$\begin{array}{l}\text { Kelompok Sumberdaya } \\
\text { lkan }\end{array}$} & \multirow{2}{*}{\begin{tabular}{|l|} 
Seat Malata \\
WPP 571 \\
\end{tabular}} & \multicolumn{2}{|c|}{ Samudera Hindia } & \multirow{2}{*}{ 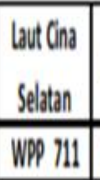 } & \multirow{2}{*}{$\frac{\text { Laut Jawa }}{\text { WPP } 712}$} & \multirow{2}{*}{\begin{tabular}{|c}
$\begin{array}{c}\text { Selat Malessar - } \\
\text { Laut Flores }\end{array}$ \\
WPP 713 \\
\end{tabular}} & \multirow{2}{*}{\begin{tabular}{|l} 
Lau Banda \\
WPP 714 \\
\end{tabular}} & \multirow{2}{*}{ 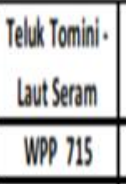 } & \multirow{2}{*}{$\begin{array}{c}\text { Laut } \\
\text { Sulawesi } \\
\text { WPP } 716 \\
\end{array}$} & \multirow{2}{*}{$\begin{array}{c}\text { Samudera } \\
\text { Pasifik } \\
\text { WPP } 717 \\
\end{array}$} & \multirow{2}{*}{\begin{tabular}{|c|}
$\begin{array}{c}\text { Lat Araturs- } \\
\text { Laut Timor }\end{array}$ \\
WPP 718 \\
\end{tabular}} & \multirow[t]{2}{*}{ Total } \\
\hline & & WPP 572 & WPP 573 & & & & & & & & & \\
\hline Kan Pelagis besar & 27,1 & 164,8 & 201,4 & 66,1 & 55,0 & 193,6 & 100,1 & 106,5 & 70,1 & 105,2 & 50,9 & $1.145,4$ \\
\hline Kan Pel|ggis Kecil & 107,3 & 315,9 & 210,6 & 62.5 & 380,0 & 605,4 & 132,0 & 379,4 & 230,9 & 153,9 & 468,7 & 3645,7 \\
\hline len Demeresal & 82,4 & 68,9 & 66,2 & 334,8 & 375,2 & 87,2 & 9,3 & 88,8 & 24,7 & 30,2 & 289,7 & $1.55,5$ \\
\hline Udann Penseid & 11,4 & 4,8 & 5,9 & 11.9 & 11,4 & 4,8 & ? & 0,9 & 1,1 & 1,4 & 4,7 & 98,3 \\
\hline Ilan Karang Konsumsi & 5,0 & 8,4 & 4,5 & 21,6 & 9,5 & 34,1 & 32,1 & 12,5 & 6,5 & 8,0 & 3,1 & 145,3 \\
\hline lobster & 0,4 & 0,6 & 1,0 & 0,4 & 0,5 & 0,7 & 0,4 & 0,3 & 0,2 & 0,2 & 0,1 & 4,8 \\
\hline Cumicumi & 1,9 & 1,7 & 2,1 & 2,7 & 5,0 & 3,9 & 0,1 & 7,1 & 0,2 & 0,3 & 3,4 & 28,3 \\
\hline $\begin{array}{c}\text { Total Potensi } \\
\text { (L.000 tonon/tatunn) }\end{array}$ & 276,0 & 565,2 & 491,1 & 1.0590 & 8366 & 929,7 & 278,0 & 595,6 & 333,6 & 299,1 & 855,5 & $6.520,1$ \\
\hline
\end{tabular}

Sumber: Keputusan Menteri Kelautan dan Perikanan No. KEP 45/MEN/2011

Sedangkan estimasi sumberdaya ikan di Wilayah Selat Makasar-Laut Flores dan Laut Arafuru-Laut Timor terlihat dalam tabel 7 berikut ini:

Tabel 7

Estimasi Potensi Sumberdaya Ikan

di Wilayah Selat Makasar-Laut Flores dan Laut Arafuru-Laut Timor

Kelompok Selat Makasar-

Sumberdaya Laut Arafur-Laut Laut Timor

Ikan Flores

\begin{tabular}{ccc}
\hline Ikan Pelagis Besar & 193.6 & 50.9 \\
Ikan Pelagis Kecil & 605.4 & 468.7 \\
Ikan Demersal & 87.2 & 284.7 \\
Udang Penaeid & 4.8 & 44.7 \\
Ikan Karang & 34.1 & 3.1 \\
Konsumsi & 0.7 & 0.1 \\
Lobster & 3.9 & 3.4 \\
Cumi-cumi & Nerikan No. KEP 45/MEN/2011 (diolah)
\end{tabular}

Wilayah perairan Selat Makasar, Laut Flores, Laut Sulawesi, dan Samudra Pasifik, Laut Arafuru serta Samudra Hindia, kegiatan penangkapan ikannya masih dapat dikembangkan, 
baik dilihat dari sisi kuantitas ketersediaan sumber daya ikannya, maupun dari sisi kelompok sumber daya ikannya. (Adrianto, dkk., 2004)

\section{Hutan mangrove.}

Menurut Nontji, (1987) dan Nybakken (1992), hutan mangrove adalah tipe hutan yang khas terdapat di sepanjang pantai atau muara sungai yang dipengaruhi oleh pasang surut air laut. Mangrove tumbuh pada pantai yang terlindung atau pantai yang datar, biasanya di sepanjang sisi pulau yang terlindung dari angin atau di belakang terumbu karang di lepas pantai yang terlindung. (dalam Anwar, dkk., 2006).

Beberapa manfaat hutan mangrove (Irwanto, 2008) dapat dikelompokan sebagai berikut:

\section{Manfaat / Fungsi Fisik:}

1. Menjaga agar garis pantai tetap stabil.

2. Melindungi pantai dan sungai dari bahaya erosi dan abrasi.

3. Menahan badai/angin kencang dari laut.

4. Menahan hasil proses penimbunan lumpur, sehingga memungkinkan terbentuknya lahan baru.

5. Menjadi wilayah penyangga, serta berfungsi menyaring air laut menjadi air daratan yang tawar.

6. Mengolah limbah beracun, penghasil $\mathrm{O} 2$ dan penyerap $\mathrm{CO} 2$.

\section{Manfaat / Fungsi Biologik:}

1. Menghasilkan bahan pelapukan yang menjadi sumber makanan penting bagi plankton, sehingga penting pula bagi keberlanjutan rantai makanan.

2. Tempat memijah dan berkembang biaknya ikan-ikan, kerang, kepiting dan udang.

3. Tempat berlindung, bersarang dan berkembang biak dari burung dan satwa lain.

4. Sumber plasma nutfah \& sumber genetik.

5. Merupakan habitat alami bagi berbagai jenis biota.

\section{Manfaat / Fungsi Ekonomik:}

1. Penghasil kayu: bakar, arang, bahan bangunan.

2. Penghasil bahan baku industri: pulp, tanin, kertas, tekstil, makanan, obat-obatan, kosmetik, dan lain-lain.

3. Penghasil bibit ikan, nener, kerang, kepiting, bandeng melalui pola tambak silvofishery.

4. Tempat wisata, penelitian dan pendidikan.

\section{Terumbu karang.}

Terumbu karang sangat bermanfaat bagi manusia sebagai tempat pariwisata, tempat menangkap ikan, pelindung pantai secara alami, dan tempat keanekaragaman hayati.

1. Fungsi pariwisata; keindahan karang, kekayaan biologi dan kejernihan airnya membuat kawasan terumbu karang terkenal sebagai tempat rekreasi.

2. Fungsi perikanan; sebagai tempat ikan-ikan karang yang harganya mahal sehingga nelayan menangkap ikan di kawasan ini.

3. Fungsi perlindungan pantai; terumbu karang tepi dan penghalang adalah pemecah gelombang alami yang melindungi pantai dari erosi, banjir pantai, dan peristiwa perusakan lainnya yang diakibatkan oleh fenomena air laut.

Terumbu karang juga memberikan kontribusi untuk akresi (penumpukan) pantai dengan memberikan pasir untuk pantai dan memberikan perlindungan terhadap desa-desa dan infrastruktur seperti jalan dan bangunan-bangunan lainnya yang berada di sepanjang pantai. Apabila dirusak, maka diperlukan milyaran rupiah untuk membuat penghalang buatan yang setara dengan terumbu karang ini. 
4. Fungsi biodiversity; ekosistem ini mempunyai produktivitas dan keanekaragaman jenis biota yang tinggi. Keanekaragaman hidup di ekosistem terumbu karang per unit area sebanding atau lebih besar dibandingkan dengan hal yang sama di hutan tropis. (Sukmara, dkk. 2001)

\section{Anggaran}

Anggaran dapat dinterpretasikan sebagai paket pernyataan perkiraan penerimaan dan pengeluaran yang diharapkan akan terjadi dalam satu atau beberapa periode mendatang (Bastian, 2001:79). Lebih lanjut, National Committee on Govermental Accounting (NCGA), mendefinisikan anggaran (budget) adalah rencana operasi keuangan, yang mencakup estimasi pengeluaran yang diusulkan, dan sumber pendapatan yang diharapkan untuk membiayainya dalam periode waktu tertentu. (dalam Bastian, 2001:79).

Anggaran berfungsi sebagai berikut: (Bastian, 2001:80).

1. Anggaran merupakan hasil akhir proses penyusunan rencana kerja.

2. Anggaran merupakan cetak biru aktivitas yang akan dilaksanakan di masa mendatang.

3. Anggaran sebagai alat komunikasi intern yang menghubungkan berbagai unit kerja dan mekanisme kerja antara atasan dan bawahan.

4. Anggaran sebagai alat pengendalian unit kerja.

5. Anggaran sebagai alat motivasi dan persuasi tindakan efektif dan efisien dalam pencapaian visi organisasi.

6. Anggaran merupakan instrument politik.

7. Anggaran merupakan instrument kebijakan fiskal.

\section{Pendampingan}

Pendampingan dapat diartikan sebagai satu interaksi yang terus menerus antara pendamping dengan anggota kelompok atau masyarakat hingga terjadinya proses perubahan kreatif yang diprakarsai oleh anggota kelompok atau masyarakat yang sadar diri dan terdidik (tidak berarti punya pendidikan formal) (http://hapmi.org/2013/01/11/

Lebih lanjut dijelaskan pula bahwa pendampingan dapat dipahami sebagai kegiatan pemberdayaan masyarakat dengan menempatkan tenaga pendamping sebagai fasilitator, komunikator, motivator dan dinamisator. Pada dasarnya, pendampingan merupakan upaya untuk menyertakan masyarakat dalam mengembangkan berbagai potensi sehingga mampu mencapai kualitas kehidupan yang lebih baik. http://greenblue-phinisi.blogspot.co.id/ 2009/06/.

\section{Peranan Dasar Pendamping}

Pada dasarnya program pendampingan (tenaga pendamping) memiliki tiga peranan dasar antara lain:

1. Penasehat Kelompok. Pendamping berperan memberikan berbagai masukan dan pertimbangan yang diperlukan oleh kelompok dalam menghadapi masalah. Pendamping tidak memutuskan apa yang perlu dilakukan, akan tetapi kelompoklah yang nantinya membuat keputusan.

2. Trainer Participatoris. Pendamping memiliki peran memberikan berbagai kemampuan dasar yang diperlukan oleh kelompok seperti mengelola rapat, pembukuan, administrasi, memecahkan masalah, mengambil keputusan dan sebagainya.

3. Link Person. Pendamping berperan sebagai penghubung masyarakat dengan lembagalembaga yang terkait (stakeholder) dan diperlukan bagi pengembangan kelompok. http://greenblue-phinisi.blogspot.co.id/2009/06/.

\section{Metode Pendampingan}

Metode pendampingan yang bisa diterapkan dalam kelompok nelayan perikanan tangkap adalah metode Sosio Ekonomis. Metode Sosio Ekonomis adalah pendekatan yang melihat 
masyarakat yang lemah dan miskin tersebut akan mampu mengatasi persoalan mereka bila kemampuan ekonomisnya ditingkatkan, misalnya dengan dibantu dalam permodalan, ketrampilan teknis produksi, pemasaran dan sebagainya. (http://www.bintans.web.id/2010/12/).

Bertolak dari uraian tersebut di atas, disadari bahwa akses permodalan bagi kelompok nelayan perikanan tangkap sangat penting sehingga dapat membantu meningkatkan produksi ikan hasil tangkapan. Disamping itu ketrampilan teknis produksi dan pemasaran ikan juga menjadi bagian penting yang perlu dipahami oleh kelompok nelayan perikanan tangkap. Hal ini yang menjadi bagian dari tugas pendamping untuk bisa memberikan pandangan dan pemikiran-pemikiran positif kepada kelompok nelayan perikanan tangkap sehingga dapat memahami teknis produksi dan jaringan pemasaran hasil tangkapan secara efisien dan efektif.

\section{Strategi Pendampingan}

Strategi pendampingan dapat disajikan melalui tahapan kegiatan berikut ini:

1. Pertemuan awal, yaitu kegiatan pengkondisian, penjelasan tujuan, penyepakatan program kerja kelompok, jadwal kegiatan, serta informasi lain yang dibutuhkan bagi kelancaran pelaksanaan pendampingan.

2. Kunjungan dan observasi lapangan, yaitu kegiatan pengamatan terhadap lokasi kegiatan kelompok nelayan perikanan tangkap maupun sarana prasarananya yang dimiliki kelompok nelayan perikanan tangkap.

3. Pembahasan hasil observasi, yaitu kegiatan mendiskusikan dan menyamakan persepsi terkait dengan hasil temuan saat observasi lapangan. Disamping itu mendiskusikan langkah-langka perbaikannya.

4. Perbaikan berdasarkan hasil observasi, yaitu kegiatan perbaikan yang dilakukan kelompok nelayan perikanan tangkap sesuai kesepakatan dan langkah-langkah perbaikan yang telah dirumuskan pada diskusi pembahasan hasil observasi.

5. Penyusunan laporan, yaitu kegiatan pendamping menyusun laporan proses dan hasil pendampingan.

6. Distribusi Laporan. Pendamping mendistribusikan laporan kegiatan pendampingan kepada Dinas Perikanan dan Kelautan secara sistematis berdasarkan schedule yang disepakati pada pertemuan awal bersama kelompok nelayan perikanan tangkap.

\section{METODE PENELITIAN}

\section{Lokasi Penelitian}

Lokasi penelitiannya di wilayah Kelurahan/Desa yang terletak di wilayah pesisir Kabupaten Ende, khususnya kelurahan/desa yang mendapatkan bantuan anggaran pendampingan kelompok nelayan perikanan tangkap.

\section{Populasi dan Sampel}

Populasi penelitian ini adalah anggota kelompok nelayan di Kabuapten Ende sejumlah 2.745 orang. Berdasarkan jumlah populasi tersebut maka penentuan sampelnya dilakukan dengan menggunakan rumus Slovin (Umar, 2002:141-142) sebagai berikut:

$$
n=\frac{N}{1+\left(N(M o e)^{2}\right)}
$$

Dimana:

$\mathrm{n} \quad=$ Jumlah sampel

$\mathrm{N}=$ Jumlah Populasi

Moe $=$ Marginal of error maximum Kesalahan yang masih ditoleransi diambil $10 \%$. 


$$
n=\frac{2.745}{1+\left(2.745(0.10)^{2}\right)}=\frac{2.745}{1+(2.745(0.01)}=\frac{2.745}{1+27.45}=\frac{2.745}{28.45}=96,4850615114=96 \text { orang }
$$

Dengan demikian, sampelnya adalah sejumlah 96 orang.

\section{Teknik Pengambilan sampel}

Penentuan sampel atau key persons ini dapat dilakukan dengan menggunakan teknik purposive sample atau sampel bertujuan (Cooper dan Schindler, 2006:139). Dilakukan dengan cara mengambil subyek didasarkan atas adanya tujuan tertentu ini diharapkan akan mendapatkan data yang akurat. Yang menjadi sample/respondendalam penelitian ini adalah Kepala Keluarga Rumah Tangga Nelayan dan Anggota Kelompok Nelayan yang mendapat bantuan serta pendampingan dari pemerintah.

\section{Jenis dan Sumber Data}

Jenis data yang diperlukan dalam penelitian ini adalah data kualitatif dan data kuantitatif. Sedangkan berdasarkan sumbernya adalah data yang berasal dari sumber primer dan sekunder. Untuk data primer diperoleh secara langsung dari responden melalui hasil wawancara atau pengamatan. Sedangkan untuk data sekunder diperoleh dari hasil publikasi pihak lain seperti instansi-instansi terkait dengan melakukan studi dokumentasi atau literatur.

\section{Teknik Pengumpulan Data}

Teknik pengumpulan data dilakukan dengan beberapa cara sebagai berikut:

1. Teknik observasi: teknik ini dilakukan dengan cara mengamati potensi sumberdaya alam pesisir yang terdapat di Kabupaten Ende. Potensi yang akan diamati adalah kondisi umum wilayah pesisir dengan berbagai sumber dayanya seperti perikanan laut, keadaan vegetasi mangrove, maupun terumbu karang yang dikelolah oleh masyarakat nelayan.

2. Teknik wawancara, dalam wawancara tersebut berpedoman pada daftar pertanyaan (kuesioner) yang bersifat tertutup dan terbuka yang akan mewawancarai setiap responden yang betul memahami kondisi sumberdaya alam pesisir, terutama anggota kelompok nelayan. Wawancara ini dilakukan secara personal (personal interviewing) artinya wawancara antar orang, yaitu antara peneliti (pewawancara) dengan responden (yang diwawancarai), yang diarahkan oleh pewawancara untuk tujuan memperoleh informasi yang relevan. Penentuan key persons ini dapat dilakukan dengan menggunakan teknik purposive sample atau sampel bertujuan (Cooper dan Schindler, 2006:139). Dilakukan dengan cara mengambil subyek didasarkan atas adanya tujuan tertentu. Pewawancara biasanya telah menyiapkan rencana wawancara, sering tertulis, yang berisi pertanyaan-pertanyaan yang difokuskan untuk menjawab masalah penelitian. (Kuncoro, 2003:139).

3. Teknik dokumentasi. Mengumpulkan data dari bahan-bahan tertulis sebagai dokumen dan bentuk lainnya seperti buku-buku, koran, majalah dan yang sejenis.

\section{Teknik Analisis Data}

Teknik analisis data yang digunakan dalam penelitian ini adalah:

1. Distribusi frekuensi untuk menganalisis peran pendamping, metode serta strategi pendampingan.

2. Analisis regresi linear model semilog dan efektifitas.

Adapaun analisis regresi lenear model semilog tersebut rumusnya adalah sebagai berikut: (Gujarati, 179 : 2004) 
Sesuai dengan variabel yang akan diteliti maka modelnya dapat dimodifikasi sebagai berikut:
$\mathrm{K}=$ Kesejahteraan masyarakat nelayan
A = Anggaran ector perikanan dan kelautan
$\wedge=$ Estimasi, Constant, Slope garis regresi
In = Logaritma natural

Analisis regresis linear model semilog digunakan untuk melihat tingkat kepekaan kondisi kesejahteraan mayarakat nelayan di Kabupaten Ende yang dipengaruhi oleh perubahan anggaran di bidang kelautan dan perikanan. Atau dapat dikatakan hasil analisis model semilog tersebut diinterpretasikan dengan mengacu pada konsep elastisitas sebagai berikut: elastisitas adalah ukuran persentase perubahan suatu variabel yang disebabkan oleh 1 persen perubahan variabel lain. (Nicholson, 2002, 132).

Analisis efektifitas digunakan untuk mengetahui efektifitas penggunaan anggaran di bidang kelautan dan perikanan terhadap kondisi kesejahteraan masyarakat nelayan di Kabupaten Ende.

\section{HASIL DAN PEMBAHASAN}

\section{Penyebaran dan Pengembalian Kuesioner}

Data penelitian dikumpulkan dengan menyebarkan sebanyak 106 kuesioner kepada responden. Kriteria responden adalah kelompok Nelayan di wilayah pesisir pantai utara dan pantai selatan Kabupaten Ende yang mendapat bantuan anggaran pendampingan dari pemerintah tahun 2011-2015.

Waktu penyebaran kuesioner berlangsung dari tanggal 10 Juli sampai dengan 10 Agustus 2016. Jumlah kuesioner yang dikembalikan sebanyak 106 eksemplar. Dari jumlah tersebut yang diisi dengan lengkap dan dapat digunakan untuk diolah datanya sebanyak 96 dan yang tidak bisa digunakan sebanyak 10 karena tidak diisi dengan lengkap sehingga tidak dapat diolah. Dengan demikian tingkat pengembalian (response rate) dari kuesioner yang disebarkan sebesar $100 \%$.

Adapun Kecamatan dan desa tempat penyebaran kuesioner adalah:

\section{Demografi Responden}

Jumlah responden yang diwawancarai adalah sejumlah 96 orang. Gambaran umum mengenai profil responden dapat dilihat pada klasifikasi berdasarkan pendidikan dan tingkat umur, seperti terlihat pada tabel 9 dan tabel 10 di bawah ini.

\section{Tabel 8}

Pendidikan Responden

\begin{tabular}{lcc}
\hline \multicolumn{1}{c}{ Pendidikan Responden } & Jumlah & $\begin{array}{c}\text { Persentase } \\
(\mathbf{\%})\end{array}$ \\
\hline Sekolah Dasar (SD) & 66 & 68.75 \\
Sekolah Lanjutan Tingkat Pertama (SLTP) & 19 & 19.79 \\
Sekolah Lanjutan Tingkat Atas (SLTA) & 10 & 10.42 \\
Diploma & 1 & 1.04 \\
\hline
\end{tabular}

Sumber: Hasil olahan

Tabel 9

Umur Responden

\begin{tabular}{ccc}
\hline Umur & Jumlah & $\begin{array}{c}\text { Persentase } \\
(\%)\end{array}$ \\
\hline $21-30$ & 2 & 2.08 \\
$31-40$ & 20 & 20.83 \\
$41-50$ & 43 & 44.79 \\
$51-60$ & 15 & 15.63 \\
\hline
\end{tabular}




\begin{tabular}{ccc}
\hline $61-70$ & 10 & 10.42 \\
$71-80$ & 6 & 6.25 \\
\hline Jumlah & $\mathbf{9 6}$ & $\mathbf{1 0 0 . 0 0}$ \\
\hline \multicolumn{2}{l}{ Sumber: Hasil olahan }
\end{tabular}

Tabel 10

Wilayah Penyebaran Kuesioner

\begin{tabular}{|c|c|c|c|c|}
\hline No & Kecamatan & Kel./Desa & $\begin{array}{c}\text { Jumlah } \\
\text { Kuesioner }\end{array}$ & Jumlah \\
\hline \multirow{4}{*}{1} & \multirow{4}{*}{ Maurole } & Aewora & 1 & \multirow{4}{*}{5} \\
\hline & & Ngalu Koja & 2 & \\
\hline & & Mausambi & 1 & \\
\hline & & Watukamba & 1 & \\
\hline \multirow{3}{*}{2} & \multirow{3}{*}{ Nangapanda } & Anaraja & 11 & \multirow{3}{*}{21} \\
\hline & & Ndorurea & 3 & \\
\hline & & Nggorea & 7 & \\
\hline \multirow{4}{*}{3} & \multirow{4}{*}{ Ende Selatan } & Paupanda & 4 & \multirow{4}{*}{16} \\
\hline & & Rukun Lima & 4 & \\
\hline & & Tanjung & 1 & \\
\hline & & Tetandara & 7 & \\
\hline \multirow{6}{*}{4} & \multirow{6}{*}{ Ende Utara } & Boro Kanda II & 2 & \multirow{6}{*}{13} \\
\hline & & Embu Ndoa & 1 & \\
\hline & & Gheogoma & 1 & \\
\hline & & Kotaraja & 2 & \\
\hline & & Kotaratu & 5 & \\
\hline & & Raterua & 1 & \\
\hline 5 & Ende Timur & Mautapaga & 1 & 1 \\
\hline \multirow{6}{*}{6} & \multirow{6}{*}{ Pulau Ende } & Paderape & 9 & \multirow{5}{*}{40} \\
\hline & & Pu'utara & 8 & \\
\hline & & Rendoraterua & 11 & \\
\hline & & Renga Menge & 4 & \\
\hline & & Redodori & 8 & \\
\hline & & TOTAL & & 96 \\
\hline
\end{tabular}

Sumber: Hasil olahan

\section{Pendamping Kelompok Nelayan.}

Tenaga pendamping yang tersedia adalah 10 orang dengan rincian 2 (dua) orang di bidang perikanan tangkap, 2 (dua) orang di bidang garam rakyat, 2 (dua) orang di bidang penguatan daya saing produk kelautan dan perikanan dan 4 (empat) orang di bidang perikanan budi daya.

Dua orang pendamping di bidang perikanan tangkap tersebut terdapat di Kecamatan Nangapanda dan Kecamatan Ende Selatan. Adapun pendamping kelompok nelayan perikanan tangkap di Kecamatan Nangapanda adalah Filmon Syanus Naro, S.IK sedangkan pendamping kelompok nelayan di Kecamatan Ende Selatan adalah Mutiara Savitri, S. Pi.

Adapun tugas dan funsgi pendamping kelompok nelayan perikanan tangkap tersebut adalah menyusun rencana kerja penyuluhan perikanan tahunan dan bulanan sesuai kebutuhan sasaran di wilayah kerja berdasarkan pusat penyuluhan dan pemberdayaan masyarakata kelautan dan perikanan; 
1. Menyusun data potensi wilayah kerja berupa: monografi wilayah, tingkat penerapan teknologi, komoditas unggulan spesifik lokasi, serta keragaan pelaku utama/usaha dan kelompok perikanan;

2. Membantu penumbuhan, penguatan dan pengembangan kelompok perikanan di wilayah kerja;

3. Menyusun materi penyuluhan perikanan sesuai kebutuhan sasaran penyuluhan;

4. Membantu meningkatkan kapasistas pelaku utama/usaha perikanan;

5. Membantu meningkatkan akses pelaku utama/usaha perikanan terhadap informasi pasar, teknologi, sarana prasarana dan pembiayaan;

6. Membantu mewujudkan usaha perikanan yang feasible dan bankable;

7. Membantu meningkatkan produktivitas dan skala usaha pelaku utama/usaha;

8. Membantu meningkatkan pendapatan dan kesejahteraan pelaku utama/usaha;

9. Membuat laporan kinerja bulanan.

Sedangkan fungsinya adalah:

1. Sebagai motivator, fasilitator, mediator dan dinamisator dalam proses pemberdayaan pelaku utama dan usaha perikanan;

2. Sebagai agen pemberdayaan masyarakat pelaku utama dan pelaku usaha perikanan dengan meningkatkan pengetahuan, sikap dan ketrampilan di bidang penangkapan, budidaya, pengolahan dan pemasaran ikan, garam dan konservasi, serta

3. Sebagai agen perubahan masyarakat pelaku utama dan usaha perikanan dalam pembangunan sektor kelautan dan perikanan melalui fasilitas akses terhadap sumber informasi, pasar, teknologi dan pembiayaan.

Dalam melaksanakan tugasnya, pendamping perikanan tangkap menyelenggarakan fungsi pendampingan pada:

a. Pengelolaan sumber daya ikan,

b. Standarisasi kapal perikanan dan alat penangkapan ikan,

c. Sertifikat awak kapal perikanan,

d. Pengelolaan pelabuhan perikanan,

e. Peningkatan usaha penangkapan ikan, serta

f. Program prioritas perikanan tangkap.

Dalam menjalankan tugas pendampingan, ada kendala yang dihadapi pendamping, yakni:

a. Ada kesulitan untuk bertemu dengan kelompok nelayan.

b. Jangkauan jarak antar kecamatan yang relatif jauh.

\section{Peran pendamping dalam memberdayakan kelompok nelayan perikanan tangkap.}

Pendamping memiliki peran yang strategis dalam proses pemberdayaan, termasuk di dalamnya adalah pemberdayaan terhadap kelompok nelayan. Bagaimana halnya dengan kelompok nelayan di wilayah operasi Dinas Perikanan dan Kelautan Kabupaten Ende.

Kelompok nelayan menunjukkan respon baik kalau aktivitasnya sebagai nelayan selalu dalam pendampingan, pembinaan, penyuluhan dan pengawasan oleh pemerintah atau juga tenaga pendamping khusus. Respon baik ini terlihat dalam tabel 11 berikut ini.

Tabel 11

Pendampingan, pembinaan, penyuluhan dan pengawasan oleh pemerintah

\begin{tabular}{lcccc}
\hline & Frequency & Percent & Valid Percent & $\begin{array}{c}\text { Cum } \\
\text { Percent }\end{array}$ \\
\hline Sangat Tidak Setuju (STS) & 2 & 2.1 & 2.1 & 2.1 \\
Tidak Setuju (TS) & 1 & 1.0 & 1.0 & 3.1 \\
Valid Netral (N) & 14 & 14.6 & 14.6 & 17.7 \\
Setuju (S) & 32 & 33.3 & 33.3 & 51.0 \\
Sangat Setuju (SS) & 47 & 49.0 & 49.0 & 100.0 \\
\hline
\end{tabular}


Sumber: Hasil olahan.

$\begin{array}{lll}96 & 100.0 & 100.0\end{array}$

Tanggapan responden atas pernyataan "Pendampingan, pembinaan, penyuluhan dan pengawasan oleh pemerintah diperlukan" menunjukkan persentase sebagai berikut "Sangat setuju" 49,0 persen atau 47 orang selanjutnya adalah "setuju" 33.3 persen atau 32 orang, sedangkan sisanya "Netral" 14,6 persen atau 14 orang, "sangat tidak setuju" 2,1 persen atau 2 orang dan "tidak setuju" 1,0 persen atau 1 (satu) orang.

Dengan kata lain berarti "Pengelolaan anggaran pendampingan terhadap kelompok nelayan membutuhkan tenaga pendamping". Tanggapan responden terkait dengan pernyataan tersebut di atas seperti terlihat dalam tabel 12 berikut ini:

Tabel 12

Pengelolaan anggaran pendampingan terhadap kelompok nelayan membutuhkan tenaga pendamping

\begin{tabular}{lcccc}
\hline & Frequency & Percent & Valid Percent & $\begin{array}{c}\text { Cum } \\
\text { Percent }\end{array}$ \\
\hline Sangat Tidak Setuju (STS) & 3 & 3.1 & 3.1 & 3.1 \\
Tidak Setuju (TS) & 19 & 19.8 & 19.8 & 22.9 \\
Valid Netral (N) & 28 & 29.2 & 29.2 & 52.1 \\
Setuju (S) & 35 & 36.5 & 36.5 & 88.5 \\
Sangat Setuju (SS) & 11 & 11.5 & 11.5 & 100.0 \\
\hline \multicolumn{1}{c}{ Total } & $\mathbf{9 6}$ & $\mathbf{1 0 0 . 0}$ & $\mathbf{1 0 0 . 0}$ & \\
\hline
\end{tabular}

Sumber: Hasil olahan

Berdasarkan tabel 12, yang menyatakan "setuju" sebesar 36,5 persen atau 35 responden, "sangat setuju" sebesar 11,5 persen atau 11 responden, sedangkan sisanya menyatakan "netral" 29,2 persen atau 28 responden, "tidak setuju" 19,8 persen atau 19 responden dan "sangat tidak setuju" sebesar 3,1 persen atau 3 responden. Meskipun kelompok nelayan mengharapkan adanya tenaga pendamping tetapi kenyataannya menunjukkan sebagian besar kecamatan wilayah pesisir belum semuanya memiliki tenaga pendamping bagi kelompok nelayan. Hal ini seperti terlihat dalam tanggapan responden terkait dengan pernyataan "Tersedia tenaga pendamping bagi kelompok nelayan", kebanyakan responden menyatakan "tidak setuju" sebesar 51,0 persen atau sebanyak 49 responden, "sangat tidak setuju" sebesar 3,1 persen atau sebanyak 3 responden, sedangkan sisanya menyatakan "netral" 34,4 persen atau 33 responde, "setuju 8,3 persen atau 8 responden dan "sangat setuju" sebesar 3,1 persen atau 3 responden. Detailnya seperti terlihat dalam tabel 13 berikut ini.

Tabel 13

Tenaga pendamping bagi kelompok nelayan.

\begin{tabular}{lcccc}
\hline & Frequency & Percent & Valid Percent & $\begin{array}{c}\text { Cum } \\
\text { Percent }\end{array}$ \\
\hline Sangat Tidak Setuju (STS) & 3 & 3.1 & 3.1 & 3.1 \\
Tidak Setuju (TS) & 49 & 51.0 & 51.0 & 54.2 \\
Valid Netral (N) & 33 & 34.4 & 34,4 & 88.5 \\
Setuju (S) & 8 & 8.3 & 8.3 & 96.9 \\
Sangat Setuju (SS) & 3 & 3.1 & 3.1 & 100.0 \\
\hline \multicolumn{1}{c}{ Total } & $\mathbf{9 6}$ & $\mathbf{1 0 0 . 0}$ & $\mathbf{1 0 0 . 0}$ & \\
\hline \multicolumn{1}{c}{ Sumber: Hasil olahan } & & & &
\end{tabular}

Oleh karena itu sehingga ada berbagai tahapan pendampingan yang tidak dialami sebagian besar kelompok nelayan di berbagai kecamatan wilayah pesisir. 
Hal ini terlihat dari rendahnya persentase jawaban "setuju" dan "sangat setuju" terhadap pernyataan-pernyataan yang berhubungan dengan tahapan pendampingan, yang akan diuraikan pada bagian 4.4 tentang pendekatan dan strategi pendampingan yang dilakukan oleh pendamping kelompok nelayan perikanan tangkap.

\section{Pendekatan dan strategi pendampingan yang dilakukan oleh pendamping kelompok nelayan perikanan tangkap.}

Pendekatan dan strategi pendampingan diuraikan sebagai berikut:

1. Pendekatan pendampingan yang dilakukan oleh pendamping kelompok nelayan perikanan tangkap.

Pendekatan pendampingan yang ditawarkan dalam pendampingan terhadap kelompok nelayan perikanan tangkap adalah pendekatan Sosio Ekonomis. Dalam pendekatan Sosio Ekonomis ini adalah pendekatan yang melihat masyarakat yang lemah dan miskin tersebut akan mampu mengatasi persoalan mereka bila kemampuan ekonomisnya ditingkatkan, misalnya dengan dibantu dalam permodalan, ketrampilan teknis produksi, pemasaran dan sebagainya. (http://www.bintan-s.web.id/2010/12/).

Dalam kaitan dengan hal tersebut, kelompok nelayan perlu diberikan informasi permodalan, kegiatan peningkatan ketrampilan teknis, pemasaran hasil tangkapan maupun pandangan dan pemikiran-pemikiran positif dari pendamping.

Berdasarkan hasil wawancara dengan kelompok nelayan terkait dengan informasi permodalan yang disampaikan pendamping sangat kurang. Hal ini terlihat dari jawaban responden terkait dengan pernyataan "Tenaga pendamping selalu memberitahukan informasi permodalan kepada kelompok nelayan". Responden menjawab "tidak setuju" sebesar 67,7 persen atau 65 orang, "sangat tidak setuju" sebesar 11,5 persen atau 11 orang, "netral" sebesar 18,8 atau 18 orang sedangkan yang menjawab "setuju" sebesar 2,1 persen atau 2 orang. Detailnya seperti terlihat dalam tabel 14 berikut:

Tabel 14

Informasi permodalan kepada kelompok nelayan.

\begin{tabular}{lcccc}
\hline & Frequency & Percent & Valid Percent & $\begin{array}{c}\text { Cum } \\
\text { Percent }\end{array}$ \\
\hline Sangat Tidak Setuju (STS) & 11 & 11.5 & 3.1 & 3.1 \\
Tidak Setuju (TS) & 65 & 67.7 & 67.7 & 79.2 \\
Valid Netral (N) & 18 & 18.8 & 18,8 & 97.9 \\
Setuju (S) & 2 & 2.1 & 2.1 & 100.0 \\
\hline \multicolumn{1}{c}{ Total } & $\mathbf{9 6}$ & $\mathbf{1 0 0 . 0}$ & $\mathbf{1 0 0 . 0}$ & \\
\hline
\end{tabular}

Sumber: Hasil olahan

Informasi kegiatan peningkatan ketrampilan teknis produksi sangat kurang. Dalam tabel 15 menyajikan tentang hasil jawaban responden berkaitan dengan pernyataan "Tenaga pendamping selalu memberitahukan informasi kegiatan peningkatan ketrampilan teknis produksi kepada kelompok nelayan"

Tabel 15

Informasi kegiatan peningkatan

ketrampilan teknis produksi kepada kelompok nelayan.

\begin{tabular}{lcccc}
\hline & Frequency & Percent & Valid Percent & $\begin{array}{c}\text { Cum } \\
\text { Percent }\end{array}$ \\
\hline Sangat Tidak Setuju (STS) & 12 & 12.5 & 12.5 & 12.5 \\
Tidak Setuju (TS) & 64 & 66.7 & 66.7 & 79.2 \\
Valid Netral (N) & 14 & 14.6 & 14.6 & 93.8 \\
Setuju (S) & 6 & 6.3 & 6.3 & 96.9 \\
\hline \multicolumn{1}{c}{ Total } & $\mathbf{9 6}$ & $\mathbf{1 0 0 . 0}$ & $\mathbf{1 0 0 . 0}$ & \\
\hline
\end{tabular}


Sumber: Hasil olahan

Berdasarkan hasil analisis yang disajikan dalam tabel 15 , diketahui jawaban responden yang "tidak setuju" sebesar 66,7 persen atau 64 orang, "sangat tidak setuju" sebesar 12,5 persen atau 12 orang, "setuju" 6,3 persen atau 6 orang, sedangkan siasanya 14,6 persen atau 14 orang menjawab "netral".

Kelompok nelayan perikanan tangkap juga kekurangan informasi pemasaran hasil tangkapannya. Hal ini terlihat dari jawaban responden terkait dengan pernyataan "Tenaga pendamping selalu memberitahukan informasi pemasaran hasil tangkapan kepada kelompok nelayan". Responden menjawab "tidak setuju" sebesar 66,7 persen atau 64 orang, jawaban "sangat tidak setuju" sebesar 12,5 persen atau 12 orang, sedangkan sisanya menjwab "setuju" sebesar 2,1 persen atau 2 orang dan "netral" 18,8 persen atau 18 orang. Secara terperinci seperti terlihat dalam tabel 16 berikut:

Tabel 16

Informasi pemasaran hasil tangkapan kepada kelompok nelayan

\begin{tabular}{lcccc}
\hline & Frequency & Percent & Valid Percent & $\begin{array}{c}\text { Cum } \\
\text { Percent }\end{array}$ \\
\hline Sangat Tidak Setuju (STS) & 12 & 12.5 & 12.5 & 12.5 \\
Tidak Setuju (TS) & 64 & 66.7 & 66.7 & 79.2 \\
Valid Netral (N) & 18 & 18.8 & 18.8 & 97.9 \\
Setuju (S) & 2 & 2.1 & 2.1 & 100.0 \\
\hline \multicolumn{1}{c}{ Total } & $\mathbf{9 6}$ & $\mathbf{1 0 0 . 0}$ & $\mathbf{1 0 0 . 0}$ & \\
\hline
\end{tabular}

Sumber: Hasil olahan

Dalam kaitan dengan pandangan dan pemikiran-pemikiran positif yang diberikan pendamping kepada kelompok nelayan sangat kurang. Hal ini seperti terlihat dalam jawaban responden berkaitan dengan pernyataan "Pendamping biasa memberikan pandangan dan pemikiran-pemikiran positif kepada kelompok nelayan perikanan tangkap sehingga dapat memahami teknis produksi dan jaringan pemasaran hasil tangkapan secara efisien dan efektif". Responden yang menjawab "tidak setuju' sebesar 66,7 persen atau 64 orang dan "sangat tidak setuju" sebesar 11,5 persen atau 11 orang. Sisanya menjawab "netral" 14,6 persen atau 14 orang, menjawab "setuju" sebesar 6,3 peresn atau 6 orang dan "sangat setuju" sebsar 1,0 persen atau 1 orang. Pandangan dan pemikiran-pemikiran positif kepada kelompok nelayan perikanan tangkap sehingga dapat memahami teknis produksi dan jaringan pemasaran hasil tangkapan secara efisien dan efektif.

Tabel 17

Informasi pemasaran hasil tangkapan kepada kelompok nelayan

\begin{tabular}{lcccc}
\hline & Frequency & Percent & Valid Percent & $\begin{array}{c}\text { Cum } \\
\text { Percent }\end{array}$ \\
\hline Sangat Tidak Setuju (STS) & 12 & 12.5 & 12.5 & 12.5 \\
Tidak Setuju (TS) & 64 & 66.7 & 66.7 & 79.2 \\
Valid Netral (N) & 14 & 14.6 & 14.6 & 92.7 \\
Setuju (S) & 6 & 6.3 & 6.3 & 99.0 \\
Sangat Setuju (SS) & 1 & 1.0 & 1.0 & 100.0 \\
\hline \multicolumn{1}{c}{ Total } & $\mathbf{9 6}$ & $\mathbf{1 0 0 . 0}$ & $\mathbf{1 0 0 . 0}$ & \\
\hline
\end{tabular}

Sumber: Hasil olahan

Pandangan dan pemikiran-pemikiran positif kepada kelompok nelayan perikanan tangkap sehingga dapat memahami teknis produksi dan jaringan pemasaran hasil tangkapan secara efisien dan efektif.

2. Strategi pendampingan yang dilakukan oleh pendamping kelompok nelayan perikanan tangkap. 
Strategi pendampingan dilakukan melalui tahapan pendampingan mulai dari tahap pertemuan awal, kunjungan dan observasi lapangan, pembahasan hasil observasi, perbaikan berdasarkan hasil observasi, penyusunan laporan, dan tahap terakhir adalah distribusi laporan kegiatan pendampingan kepada instansi terkait.

Berdasarkan hasil penelitian diperoleh jawaban responden berkaitan dengan pertemuan awal pendamping dengan kelompok nelayan perikanan tangkap. Berikut ini adalah tabel jawaban responden atas pernyataan "Ada pertemuan awal yang dilakukan tenaga pendamping sebelum melakukan kegiatan pendampingan terhadap kelompok nelayan".

Tabel 18

Pertemuan awal yang dilakukan tenaga pendamping

\begin{tabular}{lcccc}
\hline & Frequency & Percent & Valid Percent & $\begin{array}{c}\text { Cum } \\
\text { Percent }\end{array}$ \\
\hline Sangat Tidak Setuju (STS) & 6 & 6.3 & 6.3 & 6.3 \\
Tidak Setuju (TS) & 58 & 60.4 & 60.4 & 66.7 \\
Valid Netral (N) & 20 & 20.8 & 20.8 & 87.5 \\
Setuju (S) & 6 & 9.4 & 9.4 & 96.9 \\
Sangat Setuju (SS) & 3 & 3.1 & 3.1 & 100.0 \\
\hline \multicolumn{1}{c}{ Total } & $\mathbf{9 6}$ & $\mathbf{1 0 0 . 0}$ & $\mathbf{1 0 0 . 0}$ & \\
\hline
\end{tabular}

Sumber: Hasil olahan

Berdasarkan hasil analisi yang disajikan dalam tabel 18, diketahui responden yang menjawab "tidak setuju" sebesar 60,4 persen atau 58 orang, "sangat tidak setuju" sebesar 6,3 persen atau 6 orang, "netral" 20,8 persen atau 20 orang, sedangkan "sangat setuju" dan "setuju" masing-masing sebesar 3,1 persen atau 3 orang dan 9,4 persen atau 9 orang.

Dalam kaitan dengan kunjungan dan observasi lapangan yang dilakukan oleh tenaga pendamping, responden menjawab "tidak setuju" sebesar 67,7 persen atau 65 orang, "sangat tidak setuju" sebesar 6,3 persen atau 6 orang, "netral" sebesar 17,7 persen atau 17 orang, sedangkan jawaban "setuju" dan "sangat setuju" secara berurutan 5,2 persen atau 5 orang dan 3,1 persen atau 3 orang. Secara lengkap disajikan dalam tabel 19 berikut:

\section{Tabel 19}

Kegiatan kunjungan dan observasi lapangan yang dilakukan oleh tenaga pendamping

\begin{tabular}{lcccc}
\hline & Frequency & Percent & Valid Percent & $\begin{array}{c}\text { Cum } \\
\text { Percent }\end{array}$ \\
\hline Sangat Tidak Setuju (STS) & 6 & 6.3 & 6.3 & 6.3 \\
Tidak Setuju (TS) & 65 & 67.7 & 67.7 & 74.0 \\
Valid Netral (N) & 17 & 17.7 & 17.7 & 91.7 \\
Setuju (S) & 5 & 5.2 & 5.2 & 96.9 \\
Sangat Setuju (SS) & 3 & 3.1 & 3.1 & 100.0 \\
\hline \multicolumn{1}{c}{ Total } & $\mathbf{9 6}$ & $\mathbf{1 0 0 . 0}$ & $\mathbf{1 0 0 . 0}$ & \\
\hline
\end{tabular}

Sumber: Hasil olahan

Kegiatan pembahasan hasil observasi lapangan yang dilakukan oleh tenaga pendamping relatif kurang. Hal ini terlihat dalam jawaban responden berkaitan dengan pernyataan "Ada kegiatan pembahasan hasil observasi lapangan yang dilakukan tenaga pendamping", dimana responden yang menjawab 'tidak setuju" sebsar 66,8 persen atau 66 orang, "sangat tidak setuju" sebesar 9,4 persen atau 9 orang, "netral" sebesar 18,8 persen atau 18 orang, 
sedangkan yang menjawab "setuju" hanya sebesar 2,1 persen atau 2 orang, dan yang menjawab "sangat setuju" sebesar 1,0 persen atau 1 orang. Secara terperinci disajikan dalam tabel 20 berikut.

Tabel 20

Kegiatan pembahasan hasil observasi lapangan yang dilakukan tenaga pendamping

\begin{tabular}{lcccc}
\hline & Frequency & Percent & Valid Percent & $\begin{array}{c}\text { Cum } \\
\text { Percent }\end{array}$ \\
\hline Sangat Tidak Setuju (STS) & 9 & 9.4 & 9.4 & 9.4 \\
Tidak Setuju (TS) & 66 & 68.8 & 68.8 & 78.1 \\
Valid Netral (N) & 18 & 18.8 & 18.8 & 96.9 \\
Setuju (S) & 2 & 2.1 & 2.1 & 99.0 \\
Sangat Setuju (SS) & 1 & 1.0 & 1.0 & 100.0 \\
\hline \multicolumn{1}{c}{ Total } & $\mathbf{9 6}$ & $\mathbf{1 0 0 . 0}$ & $\mathbf{1 0 0 . 0}$ & \\
\hline
\end{tabular}

Sumber: Hasil olahan

Kegiatan penyusunan laporan hasil proses pendampingan relatif kurang juga. Berikut ini jawaban responden berkaitan dengan pernyataan "Pendamping menyusun laporan proses dan hasil pendampingan". Responden menjawab "tidak setuju" sebesar 68,8 persen atau 66 orang, "sangat tidak setuju" sebesar 9,4 persen atau 9 orang, "netral" sebesar 15,6 persen atau 15 orang dan "setuju" sebesar 6,3 persen atau 6 orang. Berikut ini adalah tabel hasil analisis berkaitan dengan pernyataan tersebut di atas.

Tabel 21

Penyusunan laporan proses dan hasil pendampingan

\begin{tabular}{lcccc}
\hline & Frequency & Percent & Valid Percent & $\begin{array}{c}\text { Cum } \\
\text { Percent }\end{array}$ \\
\hline Sangat Tidak Setuju (STS) & 9 & 9.4 & 9.4 & 9.4 \\
Tidak Setuju (TS) & 66 & 68.8 & 68.8 & 78.1 \\
Valid Netral (N) & 15 & 15.6 & 15.6 & 93.8 \\
Setuju (S) & 6 & 6.3 & 6.3 & 100.0 \\
\hline \multicolumn{1}{c}{ Total } & $\mathbf{9 6}$ & $\mathbf{1 0 0 . 0}$ & $\mathbf{1 0 0 . 0}$ & \\
\hline
\end{tabular}

Sumber: Hasil olahan

Laporan hasil penelitian didistribusikan kepada Dinas Perikanan dan Kelautan secara sistematis dan berdasarkan schedule (jadawal kegiatan) pendampingan. Namun berdasarkan hasil analisis jawaban dari responden, yang menjawab "tidak setuju" cukup besar yakni 68,8 persen atau 66 orang, yang menjawab "sangat tidak setuju" sebesar 8,3 persen atau 8 orang, "netral" sebesar 20,8 persen atau 20 orang dan "setuju" sebesar 2,1 persen atau 2 orang. Berikut ini adalah tabel jawaban responden terhadap pernyataan "Pendamping mendistribusikan laporan kegiatan pendampingan kepada Dinas Perikanan dan Kelautan secara sistematis berdasarkan schedule (jadwal kegiatan) pendampingan".

Tabel 22

Pendistribusian laporan kegiatan pendampingan kepada Dinas Perikanan dan Kelautan

\begin{tabular}{lcccc}
\hline & Frequency & Percent & Valid Percent & $\begin{array}{c}\text { Cum } \\
\text { Percent }\end{array}$ \\
\hline Sangat Tidak Setuju (STS) & 8 & 8.3 & 8.3 & 8.3 \\
Tidak Setuju (TS) & 66 & 68.8 & 68.8 & 77.1 \\
Valid Netral (N) & 20 & 20.8 & 20.8 & 97.9 \\
Setuju (S) & 2 & 2.1 & 2.1 & 99.0 \\
\hline \multicolumn{1}{c}{ Total } & $\mathbf{9 6}$ & $\mathbf{1 0 0 . 0}$ & $\mathbf{1 0 0 . 0}$ & \\
\hline
\end{tabular}

Sumber: Hasil olahan 
Dampak anggaran di bidang kelautan dan perikanan terhadap kondisi kesejahteraan Mayarakat Nelayan di Kabupaten Ende.

Kesejahteraan ini terdiri dari kebutuhan dasar yang bersifat material (kebendaan) maupun bukan material, yang mencakup kesehatan, pengetahuan, dan kekayaan materi.

Dalam mengkaji kesejahteraan masyarakat kelompok nelayan perikanan tangkap ini, indikator yang dilihat adalah:

\section{Kesehatan}

Berkaitan dengan kesehatan masyarakat kelompok nelayan diperoleh tanggapan dari responden terkait dengan pernyataan "biaya pengobatan terjangkau oleh nelayan" dan responden mejawab "sangat terjangkau" sebesar 4,2 persen atau 4 orang, "terjangkau" 85 persen atau 85 orang dan "tidak terjangkau" 7,3 persen atau 7 orang. Secara detail terlihat dalam tabel 23 berikut:

Tabel 23

Jangkauan Biaya Pengobatan

\begin{tabular}{ccccc}
\hline & Frequency & Percent & Valid Percent & $\begin{array}{c}\text { Cum } \\
\text { Percent }\end{array}$ \\
\hline Sangat Terjangkau & 4 & 4.2 & 4.2 & 4.2 \\
Terjangkau & 85 & 88.5 & 88.5 & 92.7 \\
Valid Tidak Terjangkau & 7 & 7.3 & 7.3 & 100.0 \\
\hline Total & $\mathbf{9 6}$ & $\mathbf{1 0 0 . 0}$ & $\mathbf{1 0 0 . 0}$ & \\
\hline
\end{tabular}

Sumber: Hasil olahan

Jumlah biaya yang dikeluarkan responden dalam kegiatan berobat dengan nominal "Rp 100.000 - Rp.500.000" sebesar 66,7 persen atau 64 orang, nominal "Rp 500.000 - Rp 1.000.000" sebesar 21,9 persen atau 21 orang, nominal "Rp. 1.000.000 - Rp.1.400.000" sebesar 2,1 persen atau 2 orang dan responden dengan biaya berobat nominal "Rp.1.500.000" sebesar 7,3 persen atau 7 orang. Secara detail disajikan dalam tabel berikut.

Tabel 24

Biaya berobat

\begin{tabular}{lcccc}
\hline & Frequency & Percent & Valid Percent & $\begin{array}{c}\text { Cum } \\
\text { Percent }\end{array}$ \\
\hline Rp. 1.500.000 & 7 & 7.3 & 7.3 & 7.4 \\
Rp. 1.000.000-Rp. 1.400.000 & 2 & 2.1 & 2.1 & 9.6 \\
Valid Rp. 500.000-Rp. 1.000.000 & 21 & 21.9 & 21.9 & 31.9 \\
Rp. 100.000- Rp. 500.000 & 64 & 66.7 & 66.7 & 100.0 \\
Total & 94 & 97.9 & & \\
\hline Missing System & 2 & 2.1 & & \\
\hline \multicolumn{1}{c}{ Total } & $\mathbf{9 6}$ & $\mathbf{1 0 0 . 0}$ & $\mathbf{1 0 0 . 0}$ & \\
\hline
\end{tabular}

Sumber: Hasil olahan

\section{Pendidikan}

Tabel 25

Pendidikan Responden

\begin{tabular}{lcc}
\hline \multicolumn{1}{c}{ Pendidikan Responden } & Jumlah & $\begin{array}{c}\text { Persentase } \\
(\mathbf{\%})\end{array}$ \\
\hline Sekolah Dasar (SD) & 66 & 68.75 \\
Sekolah Lanjutan Tingkat Pertama (SLTP) & 19 & 19.79 \\
Sekolah Lanjutan Tingkat Atas (SLTA) & 10 & 10.42 \\
Diploma & 1 & 1.04 \\
\hline
\end{tabular}

Sumber: Hasil olahan 
Dari tabel 25 diketahui bahwa responden berpendidikan Sekolah Dasar (SD) sejumlah 66 orang atau 68,75 persen, Sekolah Lanjutan Tingkat Pertama (SLTP) sejumlah 19 orang atau 19,79 persen, Sekolah Lanjutan Tingkat Atas (SLTA) sejumlah 10 orang atau 10,42 persen dan berpendidikan Diploma sejumlah 1 orang atau 1,04 persen.

Disamping pendidikan responden, perkembangan gambaran upaya responden untuk meningkatkan pendidikan keluarga juga bisa tercermin dari variasi jawaban responden atas pernyataan "Apakah penghasilan yang ada saudara mampu membiayai pendidikan anak". Ada responden yang menjawab "sangat mampu" sebesar 2,1 persen atau 2 orang, menjawab "mampu" sebesar 85,4 persen atau 82 orang, memberiakn jawaban tidak mampu sebesar 9,4 persen atau 9 orang, dan yang menjawab sangat tidak mampu sebesar 1,0 persen atau 1 orang, sedangkan sisanya 2,1 persen atau 2 orang tidak memberikan jawaban (missing). Uraian tersebut di atas disajikan dalam tabel 26.

Tabel 26

Kemampuan membiayai pendidikan anak

\begin{tabular}{lcccc}
\hline & Frequency & Percent & Valid Percent & $\begin{array}{c}\text { Cumulative } \\
\text { Percent }\end{array}$ \\
\hline Sangat mampu & 2 & 2.1 & 2.1 & 2.1 \\
Mampu & 82 & 85.4 & 87.2 & 89.4 \\
Valid Tidak mampu & 9 & 9.4 & 9.6 & 98.9 \\
Sangat tidak mampu & 1 & 1.0 & 1.1 & 100.0 \\
$\quad$ Total & 94 & 97.9 & 100.0 & \\
\hline \multicolumn{1}{c}{ Total } & $\mathbf{9 6}$ & $\mathbf{1 0 0 . 0}$ & & \\
\hline
\end{tabular}

Sumber: Hasil olahan

Hal ini dapat dilihat dari jumlah anak-anak dari responden yang sedang melanjutkan pendidikan. Sedang membiayai pendidikan anak sebanyak " 5 orang" sebesar 11,5 persen atau 11 orang, sedang membiayai pendidikan anak sebanyak "3-4 orang" sebesar 12,6 persen atau 12 orang, membiayai pendidikan anak sebanyak "2-3 orang" sebesar 24,0 persen atau 23 orang dan yang sedang membiayai pendidikan anak sebanyak "1-2 orang" sebesar 49,0 persen atau 47 orang, sedangkan sisanya sebesar 3,1 persen atau 3 orang tidak memberikan jawaban (missing). Uraian seperti terlihat dalam tabel 27.

Tabel 27

Jumlah anak yang sedang melanjutkan pendidikan

\begin{tabular}{rcccc}
\hline & Frequency & Percent & Valid Percent & $\begin{array}{c}\text { Cumulative } \\
\text { Percent }\end{array}$ \\
\hline 5 orang & 11 & 11.5 & 11.8 & 11.8 \\
3 - 4 orang & 12 & 12.5 & 12.9 & 24.7 \\
Valid 2 - 3 orang & 23 & 24.0 & 24.7 & 49.5 \\
$1-2$ orang & 47 & 49.0 & 50.5 & 100.0 \\
Total & 93 & 96.9 & 100.0 & \\
\hline Total & $\mathbf{9 6}$ & $\mathbf{1 0 0 . 0}$ & & \\
\hline
\end{tabular}

Sumber: Hasil olahan

Jumlah anak yang sedang melanjutkan pendidikan tersebut di atas terdistribusi dalam jenjang Sekolah Dasar sampai dengan jenjang Perguruan Tinggi. Seperti tabel 28.

Tabel 28

Pendidikan anak-anak Responden yang sementara dijalani

\begin{tabular}{ccccc}
\hline Pendidikan Responden & Frequency & Percent & Valid Percent & $\begin{array}{c}\text { Cumulative } \\
\text { Percent }\end{array}$ \\
\hline Perguruan tinggi & 14 & 14.6 & 15.4 & 15.4 \\
SLTA & 37 & 38.5 & 40.7 & 56.0 \\
\hline
\end{tabular}




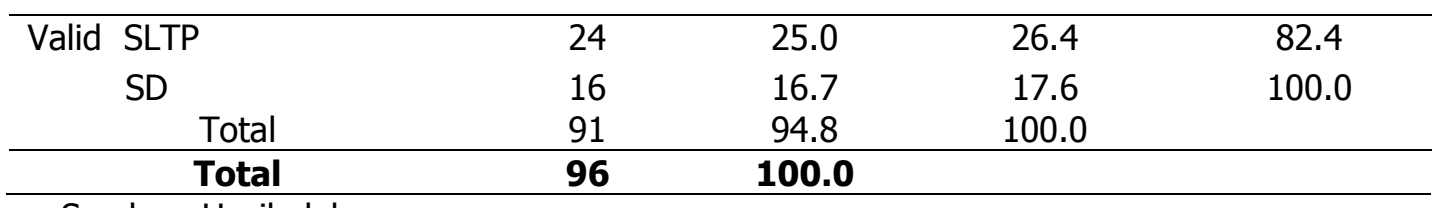

Sumber: Hasil olahan

Berdasarkan tabel 28 diketahui anak yang sedang berada pada jenjang "Perguruan tinggi" sebesar 14,6 persen atau 14 orang, "SLTA" sebesar 38,5 persen atau 37 orang, "SLTP" sebesar 25,0 atau 24 orang, "SD" sebesar 16,7 persen atau 16 orang sedangkan sisanya sebesar 5,2 persen atau 5 orang tidak merespon atas pernyataan "Status pendidikan anakanak yang sementara dijalani".

\section{Perumahan dan Lingkungan}

Kondisi rumah kelompok nelayan perikanan tangkap diketahui "permanen / rumah tembok" sebesar 68,8 persen atau 66 orang, "beratap seng dan berdinding bebak/bambu lantai semen" sebesar 25,0 persen atau 24 orang, "beratap seng dan berdinding bebak/bambu lantai tanah" sebesar 5,2 persen atau 5 orang, "beratap daun dan berdinding bebak/bambu lantai tanah" sebesar 1,0 persen atau 1 orang. Secara rinci seperti tabel 29:

Tabel 29

Kondisi rumah tempat tinggal nelayan yang ditempati

\begin{tabular}{lcccc}
\hline & Frequency & Percent & Valid Percent & $\begin{array}{c}\text { Cumulative } \\
\text { Percent }\end{array}$ \\
\hline $\begin{array}{l}\text { Permanen/Rumah tembok } \\
\begin{array}{l}\text { Beratap seng dan berdinding } \\
\text { bamboo lantai semen }\end{array}\end{array}$ & 66 & 68.8 & 68.8 & 68.8 \\
$\begin{array}{l}\text { Valid Beratap seng dan } \\
\text { berdinding bamboo lantai } \\
\text { tanah }\end{array}$ & 5 & 25.0 & 25.0 & 93.8 \\
$\begin{array}{l}\text { Beratap daun dan berdinding } \\
\text { bamboo lantai tanah }\end{array}$ & 1 & 5.2 & 5.2 & 99.0 \\
\hline \multicolumn{1}{c}{ Total } & $\mathbf{9 6}$ & $\mathbf{1 0 0 . 0}$ & $\mathbf{1 0 0 . 0}$ & 100.0 \\
\hline
\end{tabular}

Sumber: Hasil olahan

Fasilitas rumah yang tersedia "Lengkap (WC, Kamar mandi)" sebesar 56.3 persen atau 54 orang, "ada WC tetapi tidak ada kamar mandi" sebesar 28,1 persen atau 27 orang, "tidak ada kamar mandi dan tidak ada WC" sebesar 11,5 persen atau 11 orang, serta "tidak tersedia" sebesar 3,1 persen atau 3 orang, sedangkan sisanya sebesar 1,0 persen atau 1 orang tidak ada jawaban (missing). Penjelasan di atas terangkum dalam tabel 30.

\section{Tabel 30}

Fasilitas rumah yang tersedia

\begin{tabular}{lcccc}
\hline & Frequency & Percent & Valid Percent & $\begin{array}{c}\text { Cumulative } \\
\text { Percent }\end{array}$ \\
\hline $\begin{array}{l}\text { Lengkap (WC, Kamar } \\
\text { mandi) }\end{array}$ & 54 & 56.3 & 56.8 & 56.8 \\
$\begin{array}{l}\text { Ada WC tetapi tidak ada } \\
\text { kamar mandi }\end{array}$ & 27 & 28.1 & 28.4 & 85.3 \\
$\begin{array}{l}\text { Valid Tidak ada kamar } \\
\text { mandi dan WC }\end{array}$ & 11 & 11.5 & 11.6 & 96.8 \\
$\begin{array}{l}\text { Tidak tersedia } \\
\text { Total }\end{array}$ & 3 & 3.1 & 3.2 & 100.0 \\
\hline \multicolumn{1}{c}{ Total } & 9 & 99.0 & 100.0 & \\
\hline
\end{tabular}

Sumber: Hasil olahan 
Secara keseluruhan dampak anggaran di bidang kelautan dan perikanan terhadap kondisi kesejahteraan Masyarakat Nelayan di Kabupaten Ende disajikan di bawah ini. Hasil pengolahan dengan menggunakan Software SPSS vesri 21 adalah sebagai berikut:

Tabel 31

\begin{tabular}{|c|c|c|}
\hline $\begin{array}{c}\text { garun Varlabel Penj } \\
\text { Variabel }\end{array}$ & Koefisien & abel hitung \\
\hline & $\mathrm{C}$ & 2.753 \\
\hline Log (anggaran) & 0.164 & 3.771 \\
\hline $\begin{array}{l}\mathrm{t} \text { tabel pada a } \\
\text { Koefisien determinasi }\end{array}$ & $\begin{array}{l}5 \% \\
(\mathrm{R} 2)\end{array}$ & $\begin{array}{l}=1,645 \\
=0.131\end{array}$ \\
\hline
\end{tabular}

Sumber: Hasil olahan

Keterangan: $\log =$ logaritma.

Tabel 31 tersebut di atas menunjukkan bahwa nilai koefisen konstanta adalah 2.753, artinya perkiraan tingkat kesejahteraan masyarakat kelompok nelayan adalah 2.753 persen pada saat anggaran pendampingan dalam keadaan tetap.

Pengaruh dari anggaran pendampingan terhadap kondisi kesejahteraan masyarakat nelayan dapat diketahui dari besarnya nilai koefisien anggaran. Dari hasil analisis (seperti terlihat dalam tabel 31), dapat dijelaskan bahwa nilai koefisien anggaran pendampingan adalah sebesar 0.164, yang artinya bahwa ketika anggaran bertambah sebesar 1 persen maka kesejahteraan masyarakat nelayan di Kabupaten Ende akan meningkat sebesar 0.164 persen. Sebaliknya jika anggaran berkurang sebesar 1 persen maka kesejahteraan masyarakat nelayan akan menurun sebesar 0.164 persen.

Pengaruh anggaran pendampingan dapat dilihat dari besar nilai uji statistik $t$ (uji $t$ ) yang dibandingkan dengan nilai $t$ tabel, dimana besarnya nilai uji t adalah sebesar 3.771 sedangkan nilai t tabelnya adalah sebesar 1,645 . Dilihat dari nilai uji t yang lebih besar dari nilai t tabel $(3.771>1,645)$, ini menunjukkan bahwa anggaran pendampingan berpengaruh signifikan terhadap kondisi kesejahteraan masyarakat nelayan.

Anggaran pendampingan mempunyai kontribusi terhadap kondisi kesejahteraan masyarakat nelayan. Hal ini dapat diketahui dari besarnya nilai koefisien determinasi (R2) yang mendapat nilai 0.131 atau 13,1 persen, sedangkan sisanya sebesar 86,9 persen disumbangkan oleh variabel lain yang tidak dimasukkan dalam model atau variabel lain yang tidak diteliti.

Bisa disadari bahwa, yang menyebabkan anggaran pendampingan berpengaruh tetapi kontribusinya kecil terhadap kesejahteraan masyarakat nelayan adalah karena faktor Sumber Daya Manusia (SDM) yang rendah dari pihak penerima anggaran pendampingan.

Tingkat pendidikan yang rendah turut mempengaruhi proses pengelolaan anggaran pendampingan yang diberikan kepada kelompok nelayan. Oleh karena itu maka membutuhkan pengembangan sumber daya manusia bidang pengelolaan wilayah pesisir. Hal ini seperti yang diamanatkan melalui Undang-Undang Nomor 27 Tahun 2007, pasal 42 ayat 2, yang menyatakan bahwa untuk meningkatkan kualitas perencanaan dan implementasi Pengelolaan Wilayah Pesisir dan Pulau-Pulau Kecil, Pemerintah melakukan penelitian dan pengembangan ilmu pengetahuan dan teknologi serta pengembangan sumber daya manusia di bidang pengelolaan Wilayah Pesisir dan Pulau-Pulau Kecil secara berkelanjutan.

Disamping tingkat pendidikan juga tenaga pendamping yang belum tersedia semuanya di setiap kelompok nelayan. Hal ini seperti terlihat dalam tanggapan responden terkait dengan pernyataan "Tersedia tenaga pendamping bagi kelompok nelayan", kebanyakan responden menyatakan "tidak setuju" sebesar 51,0 persen atau sebanyak 49 responden, "sangat tidak setuju" sebesar 3,1 persen atau sebanyak 3 responden, sedangkan sisanya menyatakan "netral" 34,4 persen atau 33 responden, "setuju 8,3 persen atau 8 responden dan "sangat setuju" sebesar 3,1 persen atau 3 responden. Selain soal pendidikan dan pendampingan, 
faktor perilaku pengguna bantuan juga turut menentukan keberhasilan dalam penggunaan bantuan tersebut. Ada bantuan yang tidak dimanfaatkan secara maksimal oleh kelompok nelayan seperti halnya ada temuan "sarana bantuan hanya dimanfaatkan oleh salah satu anggota kelompok, sedangkan yang lain tidak berpartisipasi dalam memanfaatkannya dengan alasan mabuk laut". (Resp. 58, 2016)

Selain itu dari segi pemberi bantuannya, ada barang bantuan yang sifatnya komplementer (saling melengkapi), namun bantuan yang diterima anggota kelompok nelayan ini hanya sebagian dari barang yang dibutuhkan oleh kelompok nelayan. Berikut ini pernyataanpernyataan dari responden dalam kaitan dengan penjelasan tersebut di atas.

1. Mohon bantuan yang lebih efektif. Kasih bantuan yang lengkap (Resp. 10, 2016).

2. Memberikan bantuan kepada masyarakat itu lengkap berupa pukat, perahu, dan mesin. Dan harus ada pendamping dari dinas terkait (Resp. 55, 2016).

Efektifitas anggaran di bidang kelautan dan perikanan terhadap kondisi kesejahteraan masyarakat Nelayan di Kabupaten Ende.

Adapun efektifitasnya dapat dihitung sebagai berikut:

\section{Tabel 32}

Efektifitas Anggaran Pendampingan Pada Kelompok Nelayan Perikanan Tangkap Tahun 2011-2015

\begin{tabular}{ccccc}
\hline Tahun & Kelompok Nelayan & Perikanan Tangkap & Efektifitas & Keterangan \\
\hline 2011 & $1,915,082,749$ & $1,608,967,549$ & 84.02 & Efektif \\
2012 & $2,224,222,000$ & $2,170,119,000$ & 97.57 & Efektif \\
2013 & $2,742,893,600$ & $2,701,000,000$ & 98.47 & Efektif \\
2014 & $3,758,251,000$ & $3,078,178,500$ & 81.90 & Efektif \\
2015 & $3,165,932,600$ & $3,039,445,600$ & 96.00 & Efektif \\
\hline
\end{tabular}

Sumber: Hasil olahan

Hasil pengukuran efektifitas menggunakan kategori nilai seperti terlihat dalam tabel 32 berikut:

\begin{tabular}{|c|c|}
\hline \multicolumn{2}{|c|}{$\begin{array}{c}\text { Tabel } 33 \\
\text { Kategori Efektifitas }\end{array}$} \\
\hline Sangat tidak efektif & $0-40 \%$ \\
\hline Tidak efektif & $40-60 \%$ \\
\hline Cukup efektif & $60-80 \%$ \\
\hline Efektif & $80-100 \%$ \\
\hline Sangat efektif & $>100 \%$ \\
\hline
\end{tabular}

Hasil analisis efektifitas memperoleh nilai 80-100 persen, yang dapat disimpulkan bahwa penggunaan anggaran pendampingan bagi kelompok nelayan tersebut efektif.

\section{KESIMPULAN}

Kelompok nelayan menunjukkan respon baik kalau aktivitasnya sebagai nelayan selalu dalam pendampingan, pembinaan, penyuluhan dan pengawasan oleh pemerintah atau juga tenaga pendamping khusus. Hal ini karena pendamping memiliki peran yang strategis dalam proses pemberdayaan, termasuk di dalamnya adalah pemberdayaan terhadap kelompok nelayan. Dalam kegiatan pendampingan menggunakan pendekatan Sosio Ekonomis, yakni pendekatan yang melihat masyarakat yang lemah dan miskin tersebut akan mampu mengatasi persoalan mereka bila kemampuan ekonomisnya ditingkatkan.

Strategi pendampingan dilakukan melalui tahapan pendampingan mulai dari tahap pertemuan awal, kunjungan dan observasi lapangan, pembahasan hasil observasi, perbaikan 
berdasarkan hasil observasi, penyusunan laporan, dan tahap distribusi laporan kegiatan pendampingan kepada instansi terkait.

Anggaran pendampingan berpengaruh signifikan dan mempunyai kontribusi terhadap kondisi kesejahteraan masyarakat nelayan.

\section{SARAN}

Pada bagian ini disampaikan saran-saran:

A. Untuk Pihak Pemerintah, dalam hal ini adalah Dinas Perikanan dan Kelautan Kabupaten Ende.

1. Wilayah pesisir pantai yang merupakan tempat pemukiman nelayan yang tersebar di 14 (empat belas) kecamatan, 51 (lima puluh satu) desa dan 2.745 (dua ribu tujuh ratus empat puluh lima) anggota kelompok nelayan. Dilihat dari wilayah yang cukup luas maka diperlukan jumlah tenaga pendamping yang bisa menjangkau seluruh wilayah tersebut. Jumlah tenaga pendamping yang ada saat ini 10 orang dengan pendamping pada kelompok nelayan perikanan tangkap sebanyak 2 (dua) orang.

2. Bantuan yang diberikan tidak sesuai dengan kebutuhan masyarakat kelompok nelayan, untuk itu maka perlu dilakukan analisis kebutuhan masyarakat kelompok nelayan sebelum pengucuran anggaran.

B. Untuk masyarakat kelompok nelayan.

1. Masyarakat kelompok nelayan perikanan tangkap perlu memelihara dengan baik berbagai fasilitas bantuan dari Dinas Kelautan dan Perikanan sehingga penggunaannya dapat berkelanjutan.

2. Masyarakat kelompok nelayan perikanan tangkap secara bersama-sama perlu seefisien mungkin dalam menggunakan fasilitas bantuan dari Dinas Kelautan dan Perikanan.

3. Masyarakat kelompok nelayan perlu membangun komunikasi intensif dengan tenaga pendamping dalam kelompoknya maupun dengan pihak Dinas Kelautan dan Perikanan Kabupaten Ende.

4. Masyarkat kelompok nelayan perikanan tangkap perlu mempertahankan kelestarian sumber daya pesisir dan kelautan.

C. Untuk pihak akademisi dan peneliti selanjutnya.

Penelitian ini masih terbatas pada peran pendamping dan dampak anggaran pendampingan bagi kelompok nelayan perikanan tangkap, maka disarankan bagi peneliti selanjutnya untuk meneliti atau menambah variabel-variabel lain yang turut berpengaruh terhadap kondisi kesejahteraan masyarakat nelayan.

\section{DAFTAR PUSTAKA}

Adrianto, Luky, Mujio, dan Yudi Wahyudin. 2004. Modul Pengenalan Konsep dan Metodologi Valuasi Ekonomi Sumber Daya Pesisir dan Laut. Pusat Kajian Sumberdaya Pesisir dan Laut-IPB. Bogor. Komitmentku.files.wordpress.com.

Anwar, Chairil dan Hendra Gunawan. 2006. Peranan Ekologis dan Sosial Ekonomis Hutan Mangrove Dalam Mendukung Pembangunan Wilayah Pesisir. www.dephut.go.id

Bastian, Indra., Dr. M.B.A. 2001. Akuntansi Sektor Publik di Indonesia. BPFE- Yogyakarta.

Bintan-s. Berbagai Metode Pendampingan. http://www.bintan-s.web.id/2010/12/berbagaimetode-pendampingan.html.

Cooper, Donal R. dan Pamela S. Schindler. 2006. Metode Riset Bisnis. Media Global Edukasi. Jakarta. 
Greenblue-phinisi. Konsep Pendampingan. http://greenblue-phinisi.blogspot.co.id/2009/06/ pendampingan- dalam-pemberdayaan.htm

Hapmi. Peranan Pendamping Masyarakat. http://hapmi.org/2013/01/11/peranan pendamping- masyarakat.

Irwanto. 2008. Hutan Mangrove dan Manfaatnya. indonesiaforest.web.com

Keputusan Menteri Kelautan Dan Perikanan Republik Indonesia Nomor Kep. 45/Men/2011 Tentang Estimasi Potensi Sumber Daya Ikan Di Wilayah Pengelolaan Perikanan Negara Republik Indonesia.

kkp.go.id. Anggaran Pendapatan Dan Belanja Negara (APBN) KKP Tahun 2015

Kuncaoro, Mudrajad. 2003. Metode Riset Untuk Bisnis \& Ekonomi. Bagaimana Meneliti \& Menulis Tesis? Erlangga. Jakarta.

Keputusan Menteri Kelautan dan Perikanan Republik Indonesia Nomor Kep.18/Men/2011, Tentang Pedoman Umum Minapolitan. Infohukum.kkp.go.id

Ramadona, Tomi. 2011. Membangun Ekonomi Bangsa Berbasis Kelautan Dan Perikanan. www.scribd.com

Siregar, Yusni Ikhwan, Prof., Dr., M.Sc., Dipl MS. Menggali Potensi Sumber Daya Laut Indonesia. usu.ac.id

Sukmara, Asep, Audrie J. Siahainenia, dan Christovel Rotinsulu. 2001. Panduan Pemantauan Terumbu Karang Berbasis-Masyarakat Dengan Metoda Manta Tow. www.crc.uri.edu.

Yuniarti. Ms, S. Pi., M. Si. 2007. Pengelolaan Wilayah Pesisir Di Indonesia (Studi Kasus: Pengelolaan Terumbu Karang Berbasis Masyarakat Di Kepulauan Riau). resources.unpad.ac.id 